\title{
The Phenomenon of Gender Inequality in Access to and Equity in University Education in Nigeria
}

\author{
Mukoro, Akpoyovwaire Samuel \\ Department of Educational Foundations and Administration, \\ College of Education, \\ Warri-Delta State, \\ Nigeria
}

\section{Doi:10.5901/mjss.2013.v4n7p129}

\begin{abstract}
Education is a fulcrum for achieving progress in all aspects of human life. This is in consonance with the 1998 World Conference on Education Commitment that higher education should be geared towards development and progress. Therefore, it is expected that higher education is equally accessible to all, all persons seeking higher education have optimal range of choice and participation of women in higher education should be emphasized. This paper, therefore, examine the meaning of gender inequality, access and equity, as well as the rationale to ensure gender equitable access in university education in Nigeria. Also, the paper highlights the trends in male and female enrolment in university education and the factors that give rise to gender inequality in equitable access to university education in Nigeria. Finally, the paper examines measures to enhance gender equitable access to university education in Nigeria.
\end{abstract}

Keywords: Gender Inequality, Access, Equity, Trends in Enrolment and University Education

\section{Introduction}

Education is a means by which a nation equips her citizens for all round development. It is a fulcrum for achieving progress in all aspects of human life, national growth and development. This is in consonance with the 1998 World Conference on Education Commitment that higher education should be geared towards development and progress. Therefore, it is expected that higher education is equally accessible to all; all persons seeking higher education have an optimal range of choice and participation of women in higher education should be emphasized (UNESCO, 2003). Section (1) (4) (c) and (5) (c) of the National Policy on Education (FRN, 2004) stipulated that there is need for equality of educational opportunities to all Nigerian children irrespective of any real or imagined disabilities, each according to his or her ability and there will be the provision of equal access to educational opportunities for all citizens of the country at the primary, secondary and tertiary levels both inside and outside the formal school system. Also, as contained in the National Policy on Education document, one goal inter alia of tertiary education within Nigerian's overall national objectives is to contribute to national development through high level relevant manpower training. In effect, if this is one of the goals higher education is set to achieve, then, all citizen education irrespective of gender is a must since education provides relevant skills to contribute to national development. As such, it is only when university education is made equitably accessible to all irrespective of race, gender, language or religion that the attainment of the desired objectives of university education can be guaranteed.

Furthermore, in an effort to ensure the attainment of the goals of university education, the Federal Government of Nigeria through Section (18) of the 1999 Constitution guaranteed that government shall direct its policy towards ensuring that there is equal and adequate educational opportunity at all levels. Section (42) (2) of the Constitution of the Federal Republic of Nigeria (FRN, 1999) on right to freedom from discrimination, 
stated that no citizen of Nigeria shall be subjected to any disability or deprivation merely by reason of the circumstance of his birth. By implication, equity or equal opportunity for all citizens is a fundamental right of the individual, which like all other such rights is not only enforceable by law but universal in nature. It is in recognition of this principle that the Universal Declaration of Human Right (1948) in Article 26 stated that everyone has the right to education and the Millennium Declaration of 2000 that resolves to promote gender equality and to stimulate sustainable development.

However, researches have proved that higher education female gender equitable access rate in Nigeria is quite unimpressive. For instance, Anho \& Onojetah (2007) reported that the cumulative under-graduate enrolment overtime in Nigeria from 1980 - 1999 revealed that there is a great disparity between enrolment of male and female. Studies (Emunemu \& Ayeni, 2003 in Nwajiuba, 2011 and Oyebade, 2008) have shown that there is a very poor level of equitably accessibility to university education in Nigeria, whether on the part of women or other educationally disadvantaged groups such as nomads, migrant fishermen and street children. Nwajiuba (2011) reported that JAMB lamented the decline in the number of female candidates who sat for the examination from 438, 703 in 2003 to 353, 834 in 2004. As noted by Ahmed (2010) a wide gulf still exists in enrolment and retention in favour of males. This means that there is gender inequality in enrolment in university education in Nigeria.

Based on this background, the paper is divided into seven sections, including the brief introduction as section one. Section two examines basic concepts of the paper viz: gender inequality, access and equity, while section three highlights the rationale to ensure gender equitable access in university education, and section four provides a highlight on the trends in male and female enrolment in university education in Nigeria. Section five highlights the factors that give rise to gender inequality in equitable access to university education, while section six examines the measures to enhance gender equitable access to university education in Nigeria. The final section concludes the paper.

\section{Concepts Clarification}

\subsection{Gender Inequality}

Gender is the socially determined roles and relation between male and female human being. It refers to a social cultural stratification of male and female individuals. This stratification also follows societal norms and values consideration that define the role male and female should play in society. Gender inequality means uneven or difference in treatment, access to provision or possession of materials or other resources (political or educational, means and power). Gender inequality is therefore a situation of uneven distribution of income, lack of access to productive inputs, such as credit and education, lack of command over property or control over earned income as well as gender bias in labour market and social exclusion between men and women (ljaiya \& Balogun, 2004). It also connotes a situation where women do not have the same rights and enlightenments as men to human, social, economic and cultural development and where women do not have equal voice in civil and political life (Evans, 2001). On the other hand, inequality is often referred to as lack of equality; being unequal in amount, size, value or rank; lack of evenness, regularity or uniformity; lack of due proportion or uneven distribution of resources (World Book, 2002). Gender inequality in access to education suggests the existence of unequal opportunities for male and female who are qualified to receive education.

\subsection{Access in Education}

Access to education stands for the number of persons enrolled in the education system in comparison with those who should have been accommodated in the system and are not. It can be described as the opportunity to participate in education sector, whether formal or informal (Ehiametalor, 2005). The Federal Republic of Nigeria (2003) presented access to education as making it possible for everyone who is entitled 
to education to receive it. This implies that the recipient has to be qualified. For example, to qualify for primary education one must have attained the stipulated age of six years, to qualify for access to secondary education, the recipient must have completed his primary education and to qualify for access to university education, one must have completed his secondary education (Alumode, 2010). Thus, access to education is the right to be educated as provided by Nigerian Constitution, the Universal Declaration of Human Rights, the Conference on Education for All (EFA) and the Dakar Framework for Action, the Ouagadougou 1992 Declaration on Education of Women and Girls, the Amman 1996 Affirmation of the Pursuit of the Goals of Jomtien, the Durban 1998 State of Commitment on Inter-African Collaboration for the Development of Education and the African Union (AU) 1997 - 2006 decade of education in Africa. All these emphasize access to education for all.

\subsection{Equity in Education}

Equity has to do with distribution; the fairness or impartiality with which a given entity has been distributed (Onwuka, 1997). According to Alumode (2010) equity in education means the provision of equal opportunities for those who are qualified to receive education without regard to differences in sex, religion, social standing and environment. This implies that all section of the society should have their fair share of access to whatever educational opportunities for self-advancement through education been distributed evenly among the strata of members of the society irrespective of circumstances of birth, ethnicity, origin, religious beliefs or social status (Tonwe, 2005). Equity in university education according to Mohammed as cited in Ene (2007) referred to the removal of obstacles to university education opportunities which are not due to natural capacities and social arrangements but which are products of social factors such as socio-economic variations. He noted that discrimination on religious grounds and gender, indigene/non-indigene dichotomy, exorbitant school fees, poverty, uneven distribution of educational resources and others could impair equity in university education.

\section{Rationale to Ensure Gender Equitable Access in University Education in Nigeria}

The need to ensure gender equitable access in university education according to Bunyi (2004) as cited in Oyebade (2008) are highlighted below:

1. Higher education institutions, especially African universities, have a critical role to play in the social and economic transformation of African societies. Increased women's participation in higher education is particularly important in the era of globalization that we live in. Globalization seems to favour those with higher levels of useful knowledge and skill (but threatens the livelihoods of the lowest skilled and low knowledge levels, and devalued by technological changes, those in traditional areas of skill). It is only through higher education that women can be sure to acquire the knowledge and skills needed to earn competitive incomes and thus lead meaningful lives in a globalized world.

2. Concern about gender issues in higher education is rife because of women's contribution to social, economic and political development. If basic education for women has produced unequalled socioeconomic benefits at the family and community levels, then higher education enables women to participate usefully in the social, political and economic lives of their communities and countries as leaders in business, in the professions and in politics. All these go to prove right, the popular adage that "when you educate a man you educate an individual, but when you educate a woman you educate a generation". 


\section{Trends in Male and Female Enrolment in University Education in Nigeria}

Evidence abound that there is disparity in gender equitable access to university education in Nigeria. Statistics showed that girls and women are educationally under represented and disadvantaged in most states of Nigeria. Okolo (2001) attested to this when she reported that the trend in male enrolment in different universities (state and federal) has continued to be higher than their female counterparts. According to her, although there is sharp increase in female enrolment, unlike before, in some universities, there is still a clear inequality between male and female enrolment in some parts of the country. She maintained that inadequate access of females to technological and scientific knowledge and managerial skills show a clear evidence of inequality at higher education level. Adeyemi \& Akpotu (2004) conducted a study on the trend and pattern of gender enrolment in Nigerian universities. The study showed gap between male and female enrolment with lower female enrolment in all aspects of the universities. The study also indicated a wide gap between science and non-science based disciplines as well as between the northern and southern parts of Nigeria. Similarly, Oke (2000) and Salman (2001) reported low enrolment of female in science and technology related courses at the university level of education. It is observed that females take the least resistance by opting for disciplines designated as feminine such as liberal arts, education, nursing and shy away from courses in sciences, engineering, medicine and mathematics. The tables below show the trends in male and female enrolment in university education in Nigeria for the period 2003 and 2008.

Table 1: Total number of universities enrolment between 2003 and 2008

\begin{tabular}{|c|c|c|c|c|c|c|c|c|c|}
\hline \multicolumn{2}{|c|}{ 2003/2004 } & \multicolumn{2}{c|}{$2004 / 2005$} & \multicolumn{2}{c|}{ 2005/2006 } & \multicolumn{2}{c|}{ 2006/2007 } & \multicolumn{2}{c|}{ 2007/2008 } \\
\hline Male & Female & Male & Female & Male & Female & Male & Female & Male & Female \\
\hline 603,176 & 443,764 & 484,217 & 353,834 & 527,180 & 390,780 & 521,170 & 391,180 & 578,715 & 455,368 \\
\hline
\end{tabular}

Source: Joint Admission and Matriculation Board, 2009

Table 2: Total number of admission offered between 2003 and 2007

\begin{tabular}{|l|l|l|l|l|l|l|l|}
\hline \multicolumn{2}{|l|}{ 2003/2004 2004/2005 } & \multicolumn{2}{l|}{ 2005/2006 } & 2006/2007 \\
\hline Male & Female & Male & Female & Male & Female & Male & Female \\
\hline 62,023 & 43,984 & 60,049 & 45,906 & 39,743 & 25,775 & 42,953 & 28,044 \\
\hline
\end{tabular}

Source: Joint Admission and Matriculation Board, 2009

The tables above showed very little progress in closing gender gaps in university enrolments over the period of 2003 and 2008. This should be a source of worry to the Federal and State Governments whose aim in the National Economic Empowerment Development System (NEEDS) is to enable every citizen to participate in the economic life of the country (Ehiametalor, 2005).

\section{Factors responsible for Gender Inequality in Equitable Access to University Education in Nigeria}

Some of these factors that result in disparity in gender equitable access to university education in Nigeria include: 


\subsection{Socio-Cultural, Customs and Local Traditions}

Socio-cultural, customs and local traditions constitute serious challenge to gender inequality in equitable access to university education in Nigeria. Cultural practices of patriarchy and sex stereotype tend to discourage females from access to university education. As noted by Safilios-Rothschild (1991) that because of the prevailing patriarchal values and cultural norms poor women do find that a large number of child often constitute the only resources they can control. They can be assisted by them in the inequitable workload they do within the household. Children especially daughters are made to serve as relief from work of their mother and have therefore limited access to education and training that could help them escape from poverty in the future. In this way, poverty is perpetuated from generation to generation and the gender gap continues to widen. Also, some parents, especially in the rural areas still have not realized the importance of education for girls. They still believe it is waste of resources since the girl will be married into another family. Agu (2004) averred that low access of women to education is attributed to the concept of women as chattels to be owned by men/socio-cultural beliefs and practices like marriage and early pregnancy. This is consistent with African Development Bank (ADB) (2002) that constraints arising from the socio-cultural norms such as forced marriages, early child bearing and rearing, gender biased teaching and educational materials, and girls responsibility for heavy domestic work at an early stage also continue to curtail women's access to education, thus making it difficult for them to acquire higher (university) and relevant education. Giving credence to this, Ezema (1999) observed that in more than 50 percent of families in Nigeria, girls are made to stay at home and away from schools to take care of children as against 12 percent boys. The result may be a far more intensive tendency to marry out females at their early ages possibly to gather money for educating the males. Culturally, the decision of which child to invest in is governed by prevailing cultural practices, and many people do not believe in investing in female children because they think that boys are more important in family continuity, since they are the representatives of the family and are better educational investment than girls. All these create inequality in equitable access to university education in favour of boys.

\subsection{Religion}

Religion has much influence on the status of women and their equitable access to university education relative to men. Alumode (2010) remarked that the Muslim culture is known for its distinctive attitudes towards women's status education, employment and fertility. According to him, the purdah system not only keeps women away from schools, it also reduces the chances of young girls who are used by purdah women to hawk their produce. This invariably affects equity in access of education.

\subsection{Socio-Economic and Poverty}

Nigeria's per capital gross domestic product is among the lowest in the world. Seven out of every ten Nigerians live on less than US $\$ 1.00$ per day. In the area of human development, Nigeria is ranked $168^{\text {th }}$ in the world (Rao in Aluede, Idogho \& Imonikhe, 2012). Therefore, due to increase in poverty, poor families with a number of children may have to make choice as to which children stay in school. It implies that due to financial challenges value is placed on education of male children, girls risk being taken out of school. Adeyemi \& Akpotu (2004) give credence to this that among the very low income earners and illiterate parents who cannot afford western education for their numerous children, many choose to send the male children to school while giving out their female children in marriage even at tender ages to raise money for the education of their brothers. Adeyemi \& Akpotu (2004) further observed that alternatively, the females are often engaged in domestic and farm labour or street hawking and related tasks that are essential to the household economy. The implication is that since it has been established that seven out of every ten Nigerian live on less than US 
$\$ 1.00$ per day, it suggests that parents financial constraints posed problem to equitable access to university education.

\section{Lapses in Policies and Processes of Eliminating Gender Inequality}

(a) Gender not being seen as a priority in the context of what is regarded as more pressing; (b) wide implementation gap between declared policy intentions and actions for organizational and social changes. While governments or higher education (universities) institutions make policy commitments to equal opportunities, these do not always translate into changes in organizational practices. International ideas are not always adhered to nationally. For example, despite being a signatory to the Convention to the Elimination of Discrimination against Women (CEDAW), and having put in place some projects for the implementation of the articles of the Convention, Nigeria has not enacted the domestic laws for the enforcement; and (c) under representation of women in enrolment, academic and management posts (Oyebade, 2008).

\section{High Tuition and Cost of Education}

Tuition fees charged by the universities are impediment to equitable access to university education in Nigeria. Most families withdraw their children due to the inability to afford the costs associated with education, such as books, lunch and other charges. These costs combined with the lost opportunity cost of having children participate in household labour, place a substantial burden on family living in extreme poverty.

\section{Measures to Enhance Gender Equitable Access to University Education in Nigeria}

In Nigeria, commendable efforts have been made at various times. For instance, the production of blueprint on women education by the Federal Government in 1987 whose provisions include:

- Increasing awareness campaigns for women's education;

- Pegging of legal age of first marriage at a minimum of 18 years for women;

- Enforcing legal provision of penalties for withdrawal of girls from school for marriage;

- Expanding facilities for "second chance" functional and literacy education for adult women;

- Providing education for women with special needs e.g. nomadic education and education for women in purdah;

- Establishing women education departments in Federal and State ministries of education; and

- Establishing women education centres by FME in all states of the Federation (Oyebade, 2008).

Also the following efforts have been made at various times to ensure equitable access to education in Nigeria:

- In 1975, the Federal Government mounted vigorous campaign for women education in all the states of the federation;

- In 1976, the Universal Primary Education (UPE) programme encourages more females to enroll in primary level which eventually boosted girls' admission into the secondary school;

- Establishing more secondary schools for girls only and mixed schooling;

- Lowering of cut-off points for admission of girls in common entrance examinations in all the Federal and State Secondary Schools in the North.

Furthermore, some few interventions to enhance gender equitable access to university education in Nigeria are highlighted. These include:

Political Commitment: Sustained political commitment to and broad stakeholders support for a culture of promoting the education of the girl child. This could be in form of lowering cut-off points for female candidates seeking admission into the universities. Although such candidates must first of all meet the stipulated minimum requirement but because of limited space, cut-off point may be lower for them. Here, 
some academics may argue that it would lower standards however, if properly plan and executed it would enhance entry of female candidates admission into the universities. As part of political commitment, Nigeria government should enforce the United Nations (1979) Convention on the Elimination of all forms of Discrimination Against Women (EDAW) which provides for equal rights for women in political and public life, equal access to education and the same choice of curricula and non-discrimination in employment. Also the Commonwealth Plan of Action on Gender and Development (CPAGD) which identifies for planners and implementers fifteen areas considered desirable for achieving gender equality should be given political commitment in Nigeria.

Bursaries and Scholarship Award: Women or girls pursuing men dominant courses like the sciences, mathematics, engineering and other vocational studies should be given enhanced bursaries and scholarships by governments.

Open and Distance Learning: Through distance learning access can be expanded to ensure increase enrolment of women or females in higher education. Even when family responsibilities and women role expectations and motherhood tasks are much on female, with distance and open e-learning mode, most female will still have unhindered equitable access to university education.

Gender-Neutral and Targeted Interventions: Some strategies are "gender-neutral", but have greater benefits for girls than boys. Example of such strategies include: reducing distance from home to school, improving quality of teaching - learning, open admission, abolishing of fees, providing early childhood development programme, making school scheduling flexible, recognizing opportunity cost, assisting with learning materials and providing scholarship/stipends. All these have positive impacts on access and retention. This may be one of the major arrears where benefits can be seen in the short term (Ahmed, 2010).

Multiple Interventions: This should be in the form of advocacy, mobilization, building partnership with Non-Governmental Organizations (NGOs)/Community Based Organizations (CBOs) and sensitization programmes. Through gender sensitivity programmes teachers can be made to become conscious of gender biases which are brought into the classroom to hinder females from active and affective participation (Alumode, 2010). According to him, parents especially those in the rural areas, should be made to understand that females are so important or even more important than male children with regard to the need for education. Also, efforts should be made to focus on how to develop the university system with appropriate cultural curriculum and learning systems that do not offend the faith of the people and curricular in schools should be reviewed with a view of removing all forms of gender biases in content (Alumode, 2010 and Okafor \& Arinze, 2012).

\section{Conclusion}

An attempt has been made in this paper to highlight the access and equity dimension of gender in university education in Nigeria. The paper examined the concepts of gender inequality, access to and equity in university education. It also touched on the rationale to ensure gender equitable access to university education, trends in male and female enrolment in university education and factors that give rise to gender inequality in equitable access to university education in Nigeria. Some policies and measure to enhance gender equitable access to university education in Nigeria were discussed. It is hoped that the discussion that the paper provided would lead to equitable access of male and female to university education in Nigeria.

\section{References}

Adeyemi, K \& Akpotu, N. (2004). Gender analysis of student enrolment in Nigerian universities. Humanity and Social Science and Law, 48 (3); $361-378$.

African Development Bank (ADB) (2002). Gender, poverty and environmental indicators on African countries. Abidjan: ADB. 
Agu, S. (2004). Gender equality, education and women empowerment: The Nigerian challenge. Multidisciplinary Journal of Research Development, 8 (2); 1 - 7.

Ahmed, U.B. (2010). Promoting the education of married adolescent girls in Northern Nigeria. Nigerian Academy of Education Year Book, (6); 191 - 206.

Alumode, B.E. (2010). Improving access to and equity in university education in Nigeria. Nigerian Academy of Education Year Book, 6; $231-256$.

Anho, J.E. \& Onojetah, S.O. (2007). Education reform and national development: Gender issues, access and equity in university education. A paper presented at the $25^{\text {th }}$ Annual Conference of the Philosophy of Education Association of Nigeria (PEAN) held at the Delta State University, Abraka, $16^{\text {th }}-21^{\text {st }}$ October.

Ehiametalor, E.T. (2005). Issues of access, equity and private sector participation in the development of education. In G.O. Akpa, S.U. Udah \& E.O. Fagbamiye (eds) Deregulating the Provision and Management of Education in Nigeria. Jos: The Nigeria Association for Educational Administration and Planning (NAEAP).

Ene, A.C. (2007). Access to and equity in university education. In J.B. Babalola, G.O. Akpa, A.O. Ayeni and O. Adedeji (eds) Access, Equity and Quality in Higher Education. NAEAP Publication.

Evans, P. (2001). Sex and gender: A world of difference. DFID Developments. Issue No. 13; 32 - 34.

Ezema, P.A. (1999). Equalizing opportunities in Nigeria for the acquisition of English for national development. In J.A. Aghenta \& T. Ismail (eds) Equalizing Opportunities in Nigeria. Zaria: Tamaza Publishing Company Ltd.

Federal Republic of Nigeria (1999). 1999 Constitution of the Federal Republic of Nigeria. Lagos: Government Printer.

Federal Republic of Nigeria (2003). Education Sector Analysis. Abuja: Federal Ministry of Education.

Federal Republic of Nigeria (2004). National Policy on Education. Lagos: NERC.

ljaiya, G.T. \& Balogun, I.O. (2004). Estimating the impact of gender inequality in education on the well-being of women in Nigeria. In V.B. Jugale (ed) Poverty, Globalization and Human Development. New Delhi: Serials Publications.

Joint Admission and Matriculation Board (2009). Statistical Analysis.

Nwajiuba, C.A. (2011). Culture and sex imbalance in higher education in Nigeria: Implications for development. Educational Research. Retrieved on $26^{\text {th }}$ March, 2013 from http://www.interejournals.org/ER

Okafor, V.E. \& Arinze, F.O. (2012). Gender accessibility and equality in education: The implication to manpower development in Nigeria. African Research Review, 6 (3).

Oke, M. (2000). Gender gap and access to secondary school science education: The way forward. WAEC Monthly Seminar Paper, 2; 103 - 113.

Okolo, A.N. (2001). Gender inequality in Nigeria: A challenge for educational advancement in a developing country. In A.U. Akubue \& D. Enyi (eds) Crisis and Challenges in Higher Education in Developing Countries: A Book of Readings. Ibadan: Wisdom Publishers Ltd.

Onwuka, C.J.A. (1997). History of Nigerian Education: Philosophical and Political Dimension. Onitsha: Geelink Publishers.

Oyebade, S.A. (2008). Gender participation in university education in Nigeria and some commonwealth countries. Retrieved on February 10, 2013 from http://nigeriaworld.com/articles/html

Safilios-Rothschild, C. (1991). Gender and poverty in Asia: Some implications for project design. The World Bank EDI Working Paper.

Salman, M.F. (2001). An investigation into female enrolment in mathematics and science at the University of llorin. Nigerian Journal of Health Education and Welfare of Special People, 5 (1); 65 - 76.

Tonwe, U.A.C. (2005). Accessibility and equity in secondary school education in Delta State in a deregulated school system. In G.O. Akpa, S.U. Udoh \& E.O. Fagbamiye (eds) Deregulating the provision and management of education in Nigeria. Jos: The Nigerian Association for Education Administration and Planning (NAEAP).

UNESCO (2003). Progress and future direction in higher education in Africa. UNESCO - Dakar Office New. Retrieved April $5^{\text {th }} 2013$ from breda@unesco.org

World Book (2002). Gender. Chicago: The World Book Inc. 